\title{
INPP5D Gene
}

National Cancer Institute

\section{Source}

National Cancer Institute. INPP5D Gene. NCI Thesaurus. Code C95111.

This gene is involved in the modulation of signaling. 